\title{
La efectividad de la tecnología de realidad aumentada en la educación STEAM
}

\section{The effectiveness of augmented reality technology in STEAM education}

\author{
Yaroslav V. Tsekhmister ${ }^{1 a}$, Tetiana M. Kotyk ${ }^{2}$, Yurii S. Matviienko ${ }^{3}$, \\ Yuliia A. Rudenko ${ }^{4}$, Vita V. Ilchuk ${ }^{5}$
}

O. O. Bogomolets National Medical University, Kyiv, Ukraine ${ }^{1}$

Vasyl Stefanyk Precarpathian National University, Ivano-Frankivsk, Ukraine ${ }^{2}$

Poltava University of Economics and Trade, Poltava, Ukraine ${ }^{3}$

South Ukrainian National Pedagogical University, Odessa, Ukraine ${ }^{4}$

Vinnytsia Mykhailo Kotsiubynskyi State Pedagogical University, Vinnytsia, Ukraine ${ }^{5}$

(iD) ORCID ID: https://orcid.org/0000-0002-7959-3691 ${ }^{1}$

(iD) ORCID ID: https://orcid.org/0000-0001-8213-83182

(iD) ORCID ID: https://orcid.org/0000-0001-9615-86193

(iD) ORCID ID: https://orcid.org/0000-0002-9253-06794

(iD) ORCID ID: https://orcid.org/0000-0001-9254-5478

Recibido: 30 de mayo de 2021

Aceptado: 27 de septiembre de 2021

\begin{abstract}
Resumen
El objetivo de este estudio es identificar el impacto del uso de tecnologías de realidad aumentada en la formación de especialistas en el campo de la educación STEAM, mediante el análisis de indicadores cognitivos como "habilidades" y "voluntad" entre estudiantes que utilizan tecnologías de realidad aumentada, y la comparación entre estos indicadores con un grupo hipotético. El estudio involucró métodos de encuesta, análisis de modelos lógicos y matemáticos del proceso educativo, análisis de factores que influyen en el proceso educativo, el método para encontrar la solución óptima, el método para identificar una muestra mínima de expertos, la proporción de recomendaciones mutuas, el método de análisis de factores mentales y una prueba t de Student. El análisis de los logros educativos mostró que el uso de tecnologías de realidad aumentada mejora significativamente el rendimiento de los estudiantes, simplificando la comprensión de sistemas y mecanismos complejos en ellos.
\end{abstract}

Palabras clave: educación STEAM, realidad aumentada, tecnologías educativas, educación.

\begin{abstract}
${ }^{\mathrm{a} C}$ Correspondencia al autor

E-mail: isenkoe374@gmail.com
\end{abstract}

The aim of this study is to identify the impact of the use of augmented reality technologies in the training of specialists in the field of STEAM education by analysing such cognitive indicators as "abilities" and "will" among students who use augmented reality technologies, and compare these indicators with a hypothetical group. The study involved survey methods, analysis of logical and mathematical models of the educational process, analysis of factors 
influencing the educational process, the method of finding the optimal solution, the method of identifying a minimum sample of experts, mutual recommendations ratio, the method of analysing mental factors, and a Student's t-test. The study showed that students of the main and control groups are ready for the comprehensive implementation of augmented reality technologies in STEAM education.

Keywords: STEAM-education, augmented reality, educational technologies, education.

\section{Introduction}

The current stage of development of society puts forward new requirements for the content and quality of higher pedagogical education, which necessitates the search for new ways to train competitive graduates who can effectively solve a set of problems in the course of professional and pedagogical activities. Specialists who not only have theoretical knowledge, but also have experience in practical work with complex technological objects are already in demand (UNESCO, 2020).

In this case, STEAM educational technology is called the most promising trend in the field of education. If we decipher each letter of STEAM, we get: Science (Natural Sciences), Technology, Engineering, Mathematics. The development of innovative economy is impossible without that (Morze et al., 2019). One of the leading researchers of STEAM education, Jolly (2017), defines the features of STEM education as a creation of products of scientific and technical industry or their prototypes; product testing and refinement; project presentation; learning to implement creative abilities and the development of organizational and communication skills (Land, 2013).

Today, the world's leading countries have developed educational strategies in the field of STEAM education and include various specialized programmes for primary, secondary and higher vocational education (Herro et al., 2017). In France, Japan, and South Africa, secondary schools and out-of-school vocational organizations develop non-formal STEAM education programmes (for example, summer camps, extracurricular activities, competitions, etc.) that draw pupils' attention to STEAM occupations and provide opportunities for different areas of STEAM education (Sinatra et al., 2017).

STEAM education is introduced not only in educational institutions of the USA and European countries, but also begins to develop actively in Ukraine (King \& English, 2016). Further development of computer technology provides an opportunity to implement increasingly revolutionary educational methods in everyday practice (Fan \& Yu, 2017). It should be noted that such technologies in many cases allow creating an atmosphere of complete 
immersion in the educational and research process involving minimal resources (You et al., 2018). The information society is being further developed, where the dominant activity is associated with the production of information products (English \& King, 2017). Information today is the same strategic resource of society as food in the "agricultural", material and energy resources in "industrial” society (Gadanidis et al., 2017).

For the other hand, the use of the term "augmented reality" in this study and the construction of a methodological system for teaching Computer Science requires a clear definition (Chen \& Lin, 2019). There is currently no uniform, universal, exhaustive or generally accepted definition for the specified term. For example, another name is often used to denote the same technology: "Extended Reality" (Bakhshi et al., 2017).

A typical augmented reality system is as follows: a computer uses a video camera to analyse the surrounding space, and the system tries to find familiar real-world objects. (Kim \& Bolger, 2017). For ease of technical implementation, objects are often highlighted with a contrasting pattern called a marker (Kelley \& Knowles, 2016). This gives the user who looks at the computer screen the feeling that a virtual object exists in the real world (Musavi et al., 2018).

Thus, the aim of the study is to identify the impact of the use of augmented reality technologies in training students majoring in STEAM by analysing cognitive indicators such as "abilities" and "will" among students who use augmented reality technologies in learning, and comparing these indicators with a hypothetical group. The following objectives were set in the course of the research: select expert groups among students of the National Technical University of Ukraine "Igor Sikorsky Kyiv Polytechnic Institute", study cognitive functions using augmented reality technologies and to compare the results with the control hypothetical group.

\section{Literary review}

Morze et al. (2020) studied the organization of STEAM education in the innovation classroom. Blended learning: theoretical analysis and strategy of implementation in the educational process of higher educational institutions is covered in the work of Buhaichuk (2016). By its part, Krutii and Hrytsyshyna (2016) touches upon the problems of STREAM education of preschool children in his work. The conceptual framework of integrated STEAM education is considered by Kelley and Knowles (2016). Bykov and Burov (2020) studied digital learning environment: new technologies and requirements for knowledge seekers. Stefanidis et al. (2019) dealt with the study of prosocial skills through multiadaptive games. English et al. (2016) investigated the 
promotion of integrated STEAM education through engineering design. STEAM as an educational design is explored in the work of Jolly (2017). Albus et al. (2021) studied the influence of virtual reality on cognitive functions in learning. The issue of virtual reality in K12 and higher education is reflected in the article by Luo et al. (2021).

\section{Methods}

The widespread introduction of innovative technologies in the educational process at all levels has led to the need to create a model for monitoring the quality of the educational process, taking into account new factors influencing the assimilation of new material. First of all, it is necessary to consider the methods used in the course of the study. Research design described on Figure 1.

\begin{tabular}{|c|c|c|c|c|}
\hline $\begin{array}{c}\text { Preperatory } \\
\text { stage }\end{array}$ & $\begin{array}{l}\text { Literature } \\
\text { review and } \\
\text { study of best } \\
\text { practices }\end{array}$ & $\begin{array}{l}\text { Signing } \\
\text { concents }\end{array}$ & $\begin{array}{l}\text { Designing the } \\
\text { practical } \\
\text { guide }\end{array}$ & $\begin{array}{l}\text { Getting } \\
\text { approval }\end{array}$ \\
\hline $\begin{array}{c}\text { Experimental } \\
\text { stage }\end{array}$ & Sampling & $\begin{array}{c}\text { Mentors } \\
\text { appointment }\end{array}$ & $\begin{array}{l}\text { Introductory } \\
\text { course }\end{array}$ & $\begin{array}{c}\text { Practical } \\
\text { programme }\end{array}$ \\
\hline $\begin{array}{c}\text { Post- } \\
\text { experimental } \\
\text { stage }\end{array}$ & $\begin{array}{l}\text { Focus group } \\
\text { interview }\end{array}$ & $\begin{array}{c}\text { Data } \\
\text { processing }\end{array}$ & $\begin{array}{c}\text { Data } \\
\text { interpretation } \\
\text { and drawing } \\
\text { conclusions }\end{array}$ & \\
\hline
\end{tabular}

Figure 1. Visualised research design

\section{Sample}

The study involved 120 fourth-year students of the National Technical University of Ukraine "Igor Sikorsky Kyiv Polytechnic Institute". Students studying in the fields of STEAM education had the opportunity to take part in the research. Such sampling and stratification section allow for a more objective study and identify patterns that will allow us to analyse the impact of augmented reality technologies on educational performance.

\section{Methods}

The following diagnostic tools (research methods) were used during the study: a study and analysis of modern psychological-pedagogical and scientific-pedagogical literature, normativelegal and organizational documents, reference literature on the research topic; questionnaires 
and interviews of students; and an analysis of the obtained results using the methods of mathematical statistics.

The questionnaires used were checked for reliability by updating the issues considered in them and the absence of possible contradictions in the answers. The research must meet the ethical criteria of integrity, respect for dignity, personal boundaries of the respondents. In the course of the study, three groups of factors influencing the professional training of students in the university were identified:

1. Factors introduced by the teaching staff in the professional training of students, as well as the factor of availability of the required quantity and quality of computer equipment (Hunter, 2017). We assume that they are known in advance - do not contain uncertainty, as the teaching staff changes relatively rarely. The computer hardware of educational institutions is also infrequently updated. For convenience, we denote these factors by $\alpha$.

2. Factors that include the content and methodological system of professional training of students, taking into account the widespread introduction of augmented reality technologies in the educational process. These factors determine the elements of solving the problem, we denote them $\chi$ for convenience.

3. Factors influencing professional training, which are introduced by the students themselves. These factors cannot be determined in advance and therefore will be considered unknown, together we denote them $\xi$.

Candidates for experts were handed questionnaires in which they had to evaluate each of the candidates for experts, that is either recommend to the expert group, or not to recommend to the expert group, or give an indefinite answer. Questionnaires were created on the basis of standard questionnaires to study the training of future professionals according to the method (Hunter, 2017). The use of the questionnaire method requires respondents to independently and consciously answer the questions.

In implementing the diagnostic function, an analysis of factors related to mental processes and biopsychic properties was performed. It was found that the factor "abilities" related to biopsychic properties, and the factor "will" relate to mental processes have the greatest impact to the level of professional training of students with the use of augmented reality technologies in STEAM education. The Stages of research are as follows:

- Determination of the research group (study group at the university);

- Psychological diagnosis using tests of ability and willpower;

- Determining the level of training in the study group;

- Determination of the control group (group in the higher educational institution); 
- Calculation of the level of professional training of students in the higher educational institution when using information and communication technologies according to the developed regression equation.

4. Criteria for evaluating the results, no differences between the actual level of professional training of students in higher educational institution using augmented reality technologies and the level calculated through the regression equation. Due to the fact that the sample of 80 people is not large, Student's $t$-test was chosen to test the adequacy of the differences between the experimental and control samples. This criterion allows checking the equality or non-equality of mean values of two, even small, samples.

\section{Instruments}

Google Forms were used for the survey. Data entry and processing was performed using Microsoft Excel and SPSS Statistics 17.0. All data are given in absolute (number of choice of answers) and relative (\% of the number of respondents) values.

\section{Results}

The impact of the identified factors related to teaching staff, as well as training and laboratory facilities on the learning process are not the subject of our study, so they will not be considered in the future. The formation of an expert group is the most important procedure, largely determining the quality of expert assessment. It is important to note that the reliability of the estimates obtained increases with increasing group size.

To fulfil this task, a group of five experts was selected $(n=5)$ consisting of heads of Departments of Management, Information Technology, Economics, Humanities and Information Security. They were asked to arrange these 22 factors in order of increasing importance. The 12th factor was chosen as the one with the most significant variance in the assessment (Table 1). 
Table 1

Ranking of study assessment factors according to Hunter (2017)

\begin{tabular}{|c|c|c|c|c|c|}
\hline \multirow{2}{*}{$\begin{array}{c}\text { Factor ordinal } \\
\text { No. }\end{array}$} & \multicolumn{5}{|c|}{ Expert ordinal No. } \\
\hline & 1 & 2 & 3 & 4 & 5 \\
\hline \multicolumn{6}{|c|}{ Studied variable ordinal No. } \\
\hline 1 & 3 & 5 & 2 & 7 & 7 \\
\hline 2 & 3 & 7 & 3 & 7 & 8 \\
\hline 3 & 1 & 2 & 3 & 8 & 5 \\
\hline 4 & 1 & 8 & 1 & 2 & 1 \\
\hline 5 & 2 & 3 & 2 & 6 & 5 \\
\hline 6 & 2 & 1 & 1 & 5 & 1 \\
\hline 7 & 4 & 1 & 1 & 1 & 1 \\
\hline 8 & 5 & 2 & 2 & 3 & 4 \\
\hline 9 & 5 & 6 & 4 & 4 & 4 \\
\hline 10 & 5 & 14 & 1 & 9 & 6 \\
\hline 11 & 7 & 7 & 3 & 10 & 7 \\
\hline 12 & 9 & 11 & 2 & 11 & 10 \\
\hline 13 & 6 & 10 & 4 & 11 & 3 \\
\hline 14 & 9 & 12 & 1 & 11 & 7 \\
\hline 15 & 9 & 13 & 1 & 11 & 6 \\
\hline 16 & 9 & 9 & 6 & 8 & 8 \\
\hline 17 & 8 & 2 & 1 & 9 & 3 \\
\hline 18 & 7 & 7 & 1 & 9 & 3 \\
\hline 19 & 11 & 16 & 4 & 9 & 10 \\
\hline 20 & 12 & 15 & 4 & 9 & 11 \\
\hline 21 & 10 & 5 & 3 & 12 & 6 \\
\hline 22 & 11 & 1 & 2 & 11 & 2 \\
\hline
\end{tabular}

Source: Compiled by Hunter (2017)

The obtained estimates are normalized according to the following rule: we determine the maximum sum of places from $\mathrm{n}=5$ experts for 22 factors, for which $5 * 22=110$, then it is necessary to determine the influence of one expert's opinion on the overall assessment, which is calculated using the ratio $X=100 / 110=0.91$ Thus, we normalize the assessment of the first expert for the $12^{\text {th }}$ factor $\left(9^{\text {th }}\right.$ place in the ranking) as follows $0.91 * 9=8.19 \%$ or the normalized figure (by dividing by $100 \%$ ) $-8.19 \% / 100 \%=0.082$; for the assessments of the second and fourth experts $\left(11^{\text {th }}\right.$ place in the ranking), respectively, $0.91 * 11=10.01 \%$, or 0.10 ; third expert ( $3^{\text {rd }}$ place in the ranking) $-0.91 * 3=2.73 \%$, or 0.027 ; and the last, fifth expert $\left(10^{\text {th }}\right.$ place in 
the ranking) $-0.91 * 10=9.10 \%$, or 0.091 in the normalized form. According to the obtained estimates of the $12^{\text {th }}$ factor, the arithmetic mean score was found for 5 experts:

$$
a_{n}=(0.082+0.10+0.027+0.10+0.091) / 5=0.08
$$

The forecast of a possible estimate $b$ of the additional $(n+1)$-th expert is made. The practical value of $\mathrm{b}$ can be predicted on the basis of estimates obtained from $\mathrm{N}$ experts, taking it equal to the assessment that deviates the most from the mean $\left(a_{n}\right)$, thus, $\mathrm{b}=0.027$. The value of $\mathrm{c}$ (measures to influence the judgments of one expert on the group assessment) is determined from the ratio:

$$
\begin{aligned}
& 1.05 \leq c \leq 1.1 \text { at } b>a_{n} ; \\
& 0.9 \leq c \leq 0.95 \text { at } b<a_{n} .
\end{aligned}
$$

As $a_{n}>b$, that is $0.08>0.027$, we choose in the range from 0.9 to 0.95 .

The minimum number of experts group is determined at the extreme values of the degree of influence of the judgments of one expert on the group assessment:

if $\mathrm{c}=0.9$, then $\mathrm{n}_{\mathrm{t}}=5.625$;

that is 6 experts in the group;

if $\mathrm{c}=0.95$, then $\mathrm{n}_{\mathrm{t}}=12.25$; that is, 12 experts in the group.

Thus, the minimum number of group members is 12 . The ranking is as follows. The factor that has the greatest impact on training is awarded the 1st place, followed by 2 nd important place and so on. In case of equal importance of factors the same rank is assigned.

$$
K_{i}^{\text {mutual }}=0.078 * 10+0.066 * 2+0.06+0.024=1 .
$$

When arranging, there was a situation when two or more factors, in terms of their degree of importance, were unclear to the experts and received one rank (place). In this case, a combined rank equal to the arithmetic mean of the places they share was calculated for each of the factors of one group (Table 2). 
Table 2

Normalized integral force of experimental factors according to Hunter (2017)

\begin{tabular}{|c|c|c|}
\hline Rank & Factor & Weight \\
\hline 1 & Desire & 0.2467 \\
\hline 2 & Knowledge & 0.1889 \\
\hline 3 & Ability & 0.1435 \\
\hline 4 & Will & 0.1113 \\
\hline 5 & Orientation & 0.0844 \\
\hline 6 & Belief & 0.0678 \\
\hline 7 & Interests & 0.0456 \\
\hline 8 & Memory & 0.0299 \\
\hline 9 & Predispositions & 0.0234 \\
\hline 10 & Attention & 0.0187 \\
\hline 11 & Thinking & 0.0145 \\
\hline 12 & Skill & 0.0099 \\
\hline 13 & Ideals & 0.0067 \\
\hline 14 & Congenital predispositions & 0.0049 \\
\hline 15 & Attainments & 0.0021 \\
\hline 16 & Habits & 0.0011 \\
\hline 17 & Perception & 0.0006 \\
\hline 18 & Feelings & 0 \\
\hline 19 & Senses & 0 \\
\hline 20 & Emotions & 0 \\
\hline 21 & Temperament & 0 \\
\hline 22 & Imagination & 0 \\
\hline
\end{tabular}

Source: Compiled by Hunter (2017)

During the test, the check was conducted in five main areas: development of models for augmented reality system, elements of augmented reality system, transformation of augmented reality model into real objects, principles of interaction with augmented reality markers, augmented reality devices (Figure 2). 


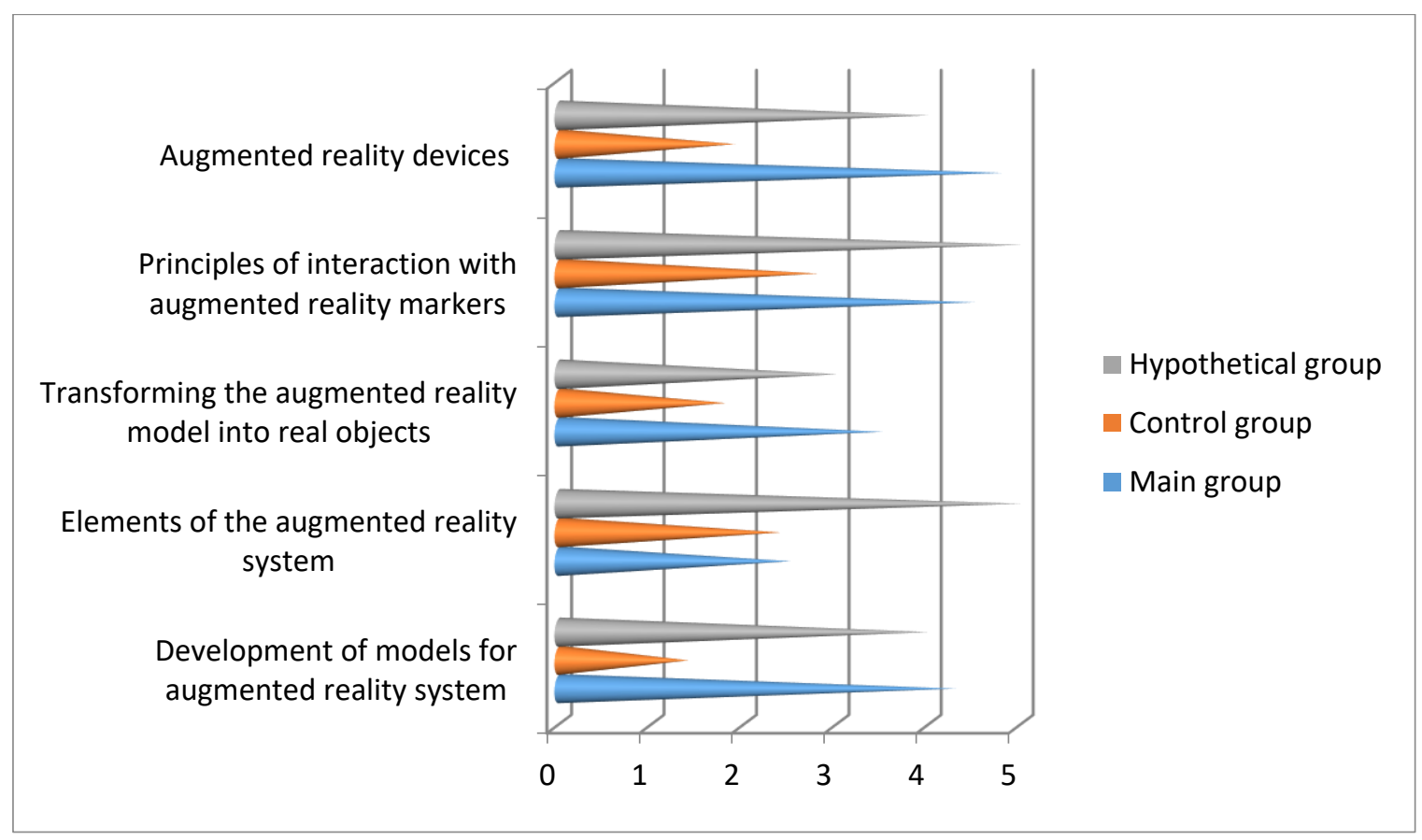

Figure 2. Assessment of mastery of the areas of implementation of augmented reality technologies among students

Source: Compiled by Hunter (2017)

During the test, the check was conducted in five main areas: development of models for augmented reality system, elements of augmented reality system, transformation of augmented reality model into real objects, principles of interaction with augmented reality markers, augmented reality devices (Figure 3). Thus, we found contradictions between the new cognitive abilities of students, which appeared due to the active computerization and informatization in the information society and the actual level of preparation of students. 


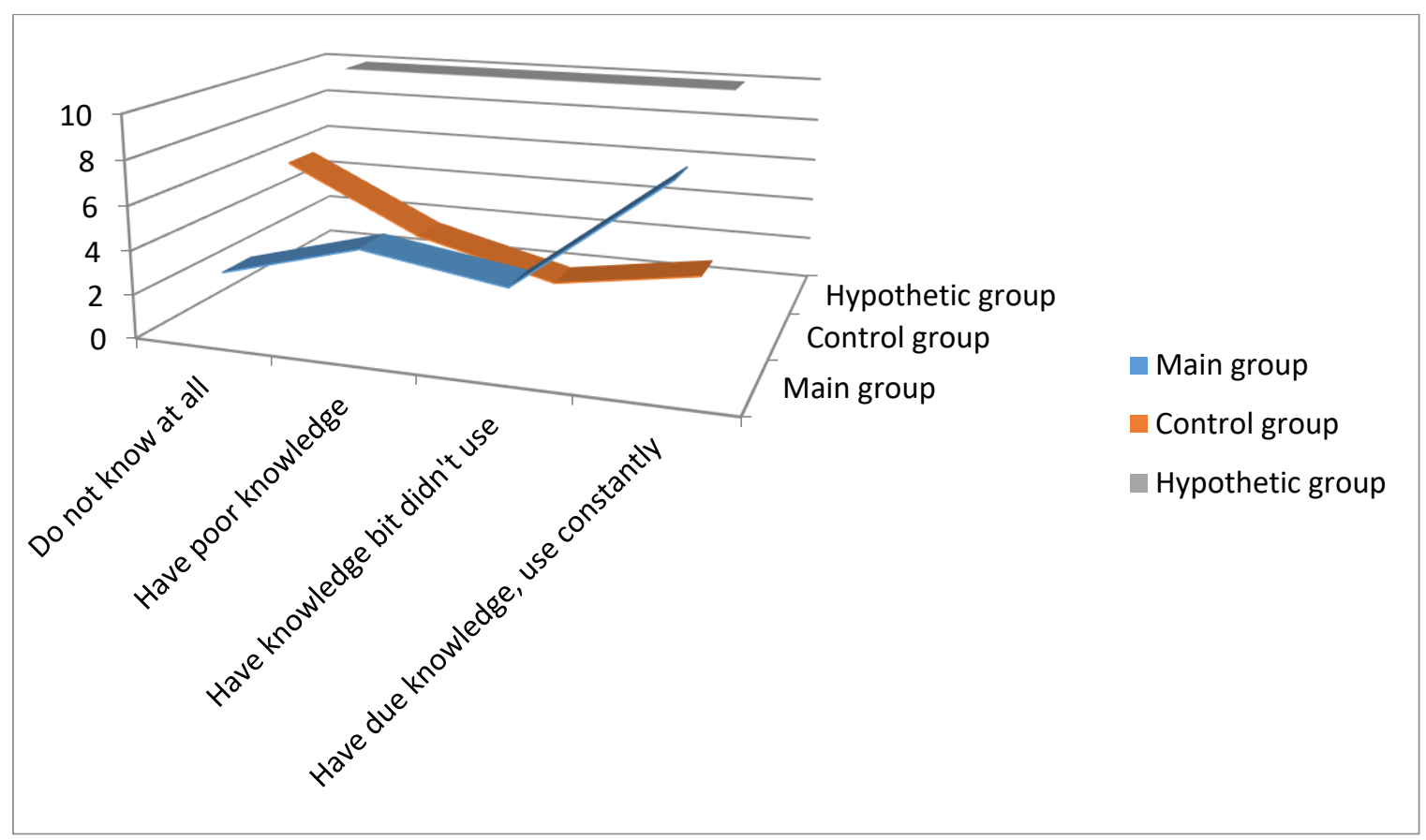

Figure 3. Research of students' awareness in the application of augmented reality technologies in education. Source: Compiled by Hunter (2017)

If we consider the generalized average score determined by the results of the first experiment before and after graduation, we can conclude that the system of augmented reality technology as an object of study introduced in the course of research is effective because it leads to the difference between the average values of this indicator in the input and final testing of 1.1 points, although the complexity of the final testing was higher than the input one (Figure 4).

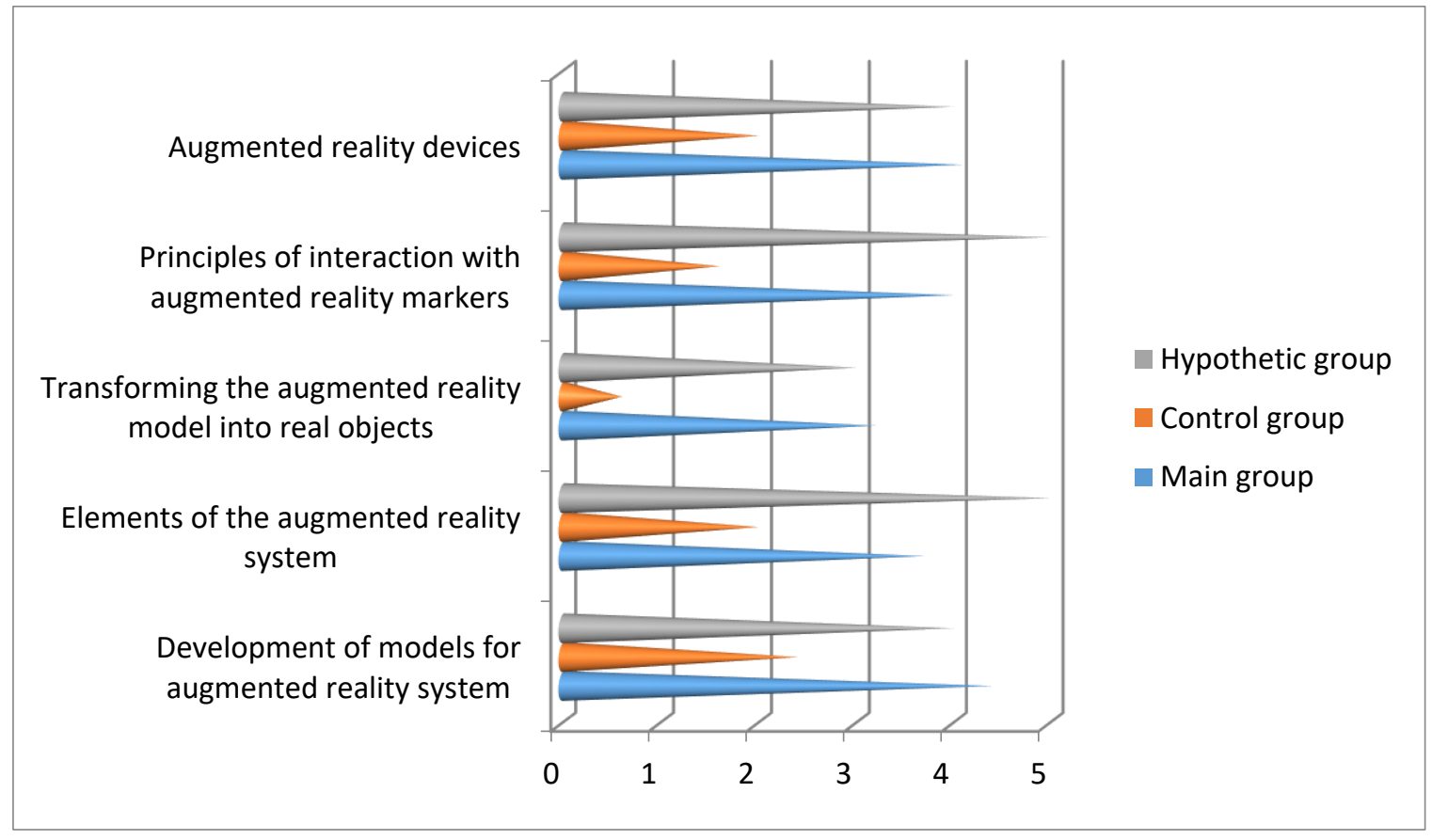

Figure 4. Indicator of mastery of areas of implementation of augmented reality technologies among students according to the analysis of success. Source: Compiled by Hunter (2017). 
Thus, the generalized level of knowledge and skills of students who took part in this experiment in the field of augmented reality technologies after studying the performance rating differs significantly from the initial level. We can conclude on this basis that students are able to effectively perceive the information included in the updated course on augmented reality technologies, which proves the second part of the hypothesis about the feasibility of expanding the course of Computer Science due to previously inaccessible practical work, as well as the inclusion of augmented reality technology as an object of study (Figure 5).

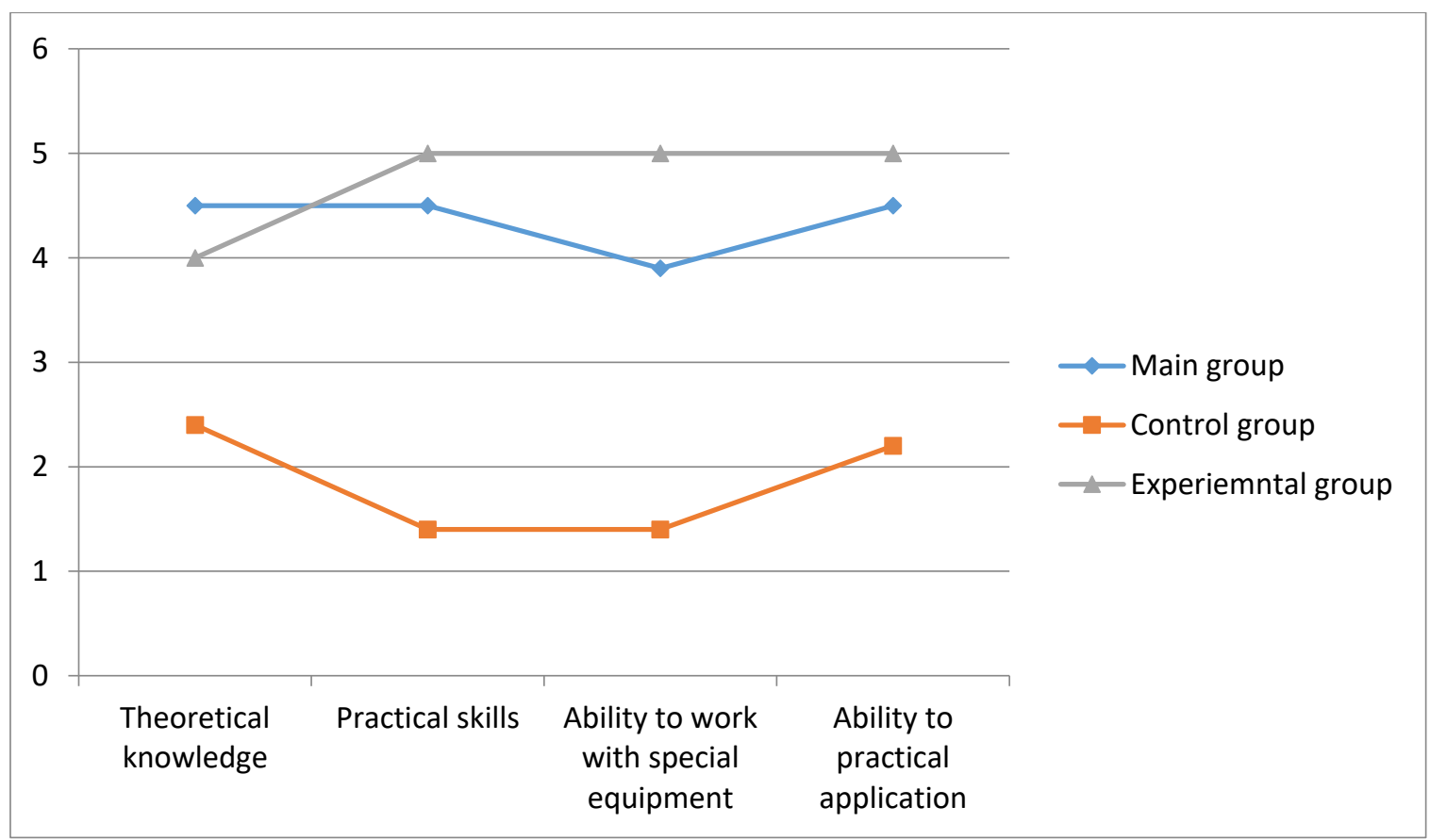

Figure 5. Distribution of average scores obtained by students based on the results of three practical assignments on the application of augmented reality technology in everyday life and possible professional activities. Source: Compiled by Hunter (2017)

For the control group, the value of asymmetry was equal to 0.14535 , which indicates a right-hand asymmetry, and the value of excess is -0.7819 , which indicates a low-vertex distribution. However, $0.14535<1.13$ and $0.7819<1.43$, which indicates that the distribution is normal with a probability of at least $95 \%$.

It is necessary to make sure that the difference is significant, because students have the knowledge, skills and abilities in the effective application of augmented reality technology, can benefit from a number of professional and everyday tasks, thus showing the reasonability of interconnected introduction of augmented reality technology as an object of study and learning aids, including for preparation for life and activity in the information society (Figure 6). 


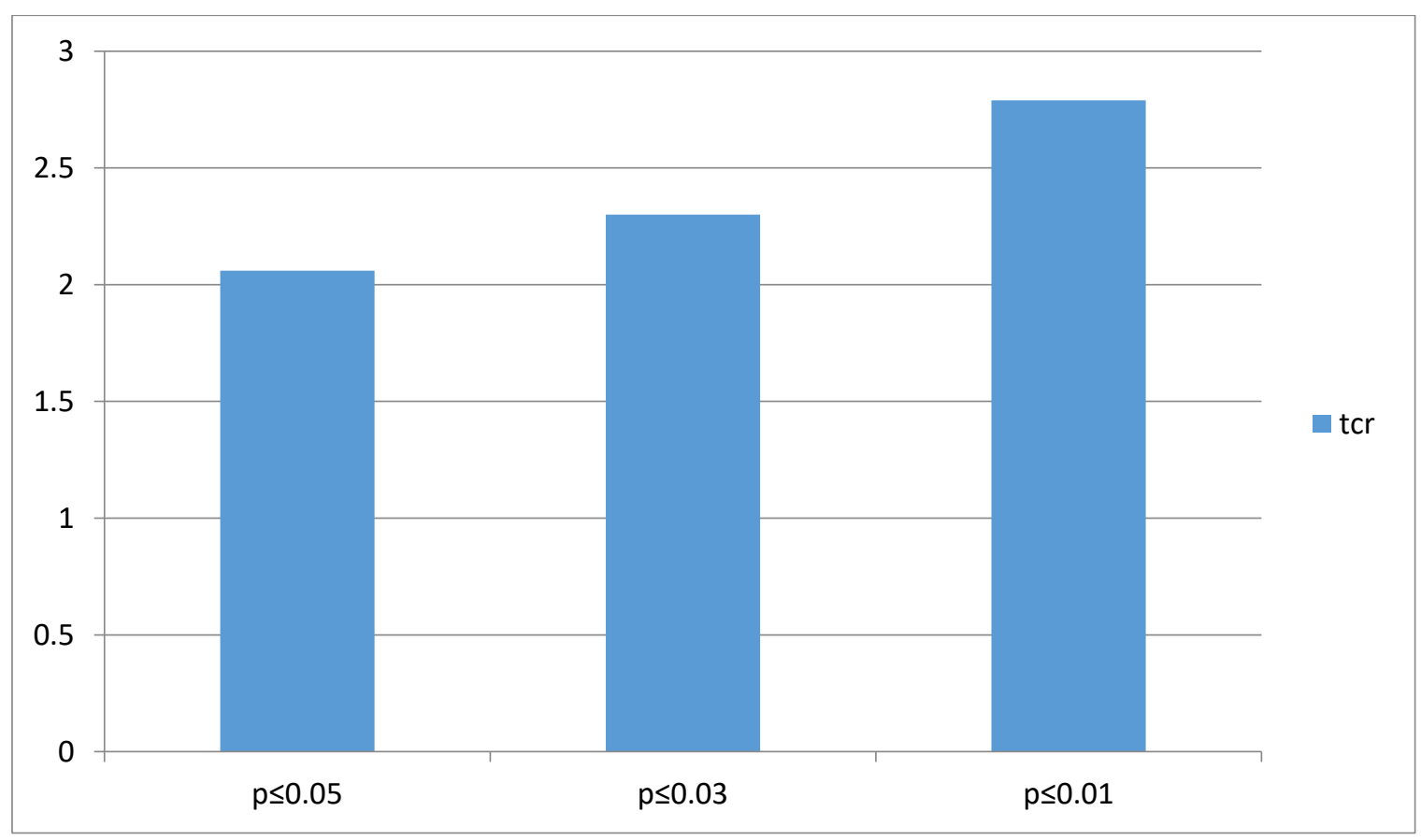

Figure 6. Critical values of Student's t-test

Source: Compiled by Hunter (2017)

You can see that $2.79>t_{\mathrm{emp}}=2.38>2.3>2.06$, which means that the probability that the hypothesis Hx is falsely high and exceeds $97 \%$, which suggests that the proposed hypothesis $\mathrm{H} 0$ is confirmed with a high probability. This means that the difference between the control and experimental groups is significant and may be due to the influence of the independent variable. Since the expected significant independent variable is the preliminary teaching Computer Science course in the experimental group, in which augmented reality technology acted interconnectedly as an object of study and a means of learning, it can be concluded that Computer Science training system can indeed increase efficiency when performing a number of tasks in everyday life and in the future professional activities using augmented reality technology.

\section{Discussions}

Information and telecommunication technologies have had a decisive influence on the emergence of another way of interpreting and implementing virtuality. The means of such technologies give a person the opportunity to feel himself/herself in virtual reality, in which he/she will not be able to distinguish between events and objects of the real and virtual worlds. The study showed a high willingness of students to participate in the introduction of augmented reality technologies in the educational process, Murphy et al. (2021) also share this position in 
their research. The perception of virtual reality depends entirely on the specifics of human consciousness, this is also noted by Kojayan and Statti (2021). Because of this, the virtual world is significantly different from the world and the sensations of everyday life.

The unique features of modern computer programs lie in the ability to animate diagrams, graphs, which are an integral part of modern education, as evidenced by the high indicators of knowledge of the main group. When studying different subjects, it is very important to trace the dynamics of the studied systems over time or depending on various parameters of the external environment or the internal manifestations of the system. Sirakaya and Sirakaya (2020) also draw attention to these factors.

It is often simply impossible to describe these complex phenomena using static diagrams and graphs or only at the verbal level, as noted by respondents from both the main and control groups. Animation of trends that describe the consequences of a management decision in Information Analytical Systems, increases the efficiency of the educational process, facilitates the learning process, as noted by the participants of the main group. You et al. (2018) draw similar conclusions, but with regard to different technical subjects.

Comprehensive multimedia presentation of the studied material in computer training programs, the use of "automated training courses", is complemented by opportunities for interactive activities of students. Programmes allow for feedback from the students during their work with the subject of study, that for organizing the students' independent work on the assimilation of the research material. It is important to note that in this case the student's learning activities take place at an individual pace.

The study showed an increase in the level of student involvement in the independent mastery of educational material using augmented reality technologies, which confirms the findings of the study by Morze et al., (2020). However, we should note the uneven distribution of positive attitudes among students of the main and control groups, who study for technical and humanitarian majors, respectively. Although the obtained data are comparable with similar studies conducted in Buhaichuk (2016), they differ in the effectiveness of the use of digital technologies for different areas of training.

Of particular value are computer programmes that allow organizing interactive games as the form of educational work. Land (2013) shares this opinion in his work. However, the organization of an effective game situation requires not only individual work of students with a computer programme, but also a collective discussion of the game by all participants, making a joint decision, as noted by King and English (2016). Thus, the most rational use of computer 
programmes with a game plot will be in the course of complex organization of students' work, both with computer equipment and without it, which is also noted by Chin and Wang (2021).

Also, according to Bakhshi et al. (2017), it is necessary to create conditions for involving students in learning instead of standardized teaching methods. That is, the conditions for partnership between students and teachers should be created to make them jointly engaged in research, and gain new knowledge.

The main limitations of the study are the difficulty of identifying the results of the study due to the uneven training of students in the field of information technology. The difficulty also lies in the development and use of modern multimedia technologies, the adequacy of the methods used to the task of research, taking into account the needs of the modern education system. Due to the quarantine due to the COVID-19 pandemic, it was difficult to test the research materials in the real educational process. The same limitations in their work were noted by Bykov and Burov (2020) and Chin and Wang (2021).

\section{Conclusions}

The topicality of this research was repeatedly proven in the article, the study of the impact of new digital technologies on the educational process is a priority of modern pedagogical science. It is possible to draw conclusions and make assumptions about the reasons why the topics and terminological framework that are so urgent today are not sufficiently developed.

Augmented reality technology obviously has significant potential in terms of expanding the scope of computer technology, but its significant application requires relatively significant computer capacity, high-quality input/output devices, compactness, specific systems for autonomy. The results of the study can be useful in planning educational programmes that include the possibility of using augmented reality technologies. Further research on this topic should be aimed at exploring a wider range of opportunities to involve the latest digital technologies in the educational process.

\section{References}

Albus, P., Vogt, A., \& Seufert, T. (2021). Signaling in virtual reality influences learning outcome and cognitive load. Computers \& Education, 166, 104154. https://doi.org/10.1016/j.compedu.2021.104154 
Bakhshi, H., Downing, J., Osborne, M., \& Schneider, P. (2017). The future of skills: Employment in 2030. London, UK: Pearson and Nesta. https://futureskills.pearson.com/research/assets/pdfs/technical-report.pdf

Buhaichuk, K. (2016). Blended learning: Theoretical analysis and strategy of implementation in educational process of higher educational institutions. Information Technologies and Learning Tools, 54 (4), 1-18. https://doi.org/10.33407/itlt.v54i4.1434

Bykov, V., \& Burov, O. (2020). Digital learning environment: New technologies and requirements for knowledge learners. Modern informational technologies and innovative methods in professional trainings: Methodology, theory, experience, problems, 55, 11-22. https://doi.org/10.31652/2412-1142-2020-55-1-268

Chen, C.-S., \& Lin, J.-W. (2019). A practical action research study of the impact of makercentered STEM-PjBL on a rural middle school in Taiwan. International Journal of Science and Mathematics Education, 17 (1), 85-108. https://doi.org/10.1007/s10763019-09961-8

Chin, K.-Y., \& Wang, C.-S. (2021). Effects of augmented reality technology in a mobile touring system on university students' learning performance and interest. Australasian Journal of Educational Technology, 37 (1), 27-42. https://doi.org/10.14742/ajet.5841

English, L. D., \& King, D. T. (2017). Engineering education with fourth-grade students: Introducing design-based problem solving. International Journal of Engineering Education, 33 (1), 346-360. https://eprints.qut.edu.au/103195/

English, L. D., King, D., \& Smeed, J. (2016). Advancing integrated STEM learning through engineering design: Sixth-grader students' design and construction of earthquake resistant buildings. Journal of Educational Research, 110 (3), 255-271. https://doi.org/10.1080/00220671.2016.1264053

Fan, S.-C., \& Yu, K.-C. (2017). How an integrative STEM curriculum can benefit students in engineering design practices. International Journal of Technology and Design Education, 27, 107-129. https://doi.org/10.1007/s10798-015-9328-X

Gadanidis, G., Hughes, J. M., Minniti, L., \& White, B. J. G. (2017). Computational thinking, grade 1 students and the binomial theorem. Digital Experiences in Mathematics Education, 3, 77-96. https://doi.org/10.1007/s40751-016-0019-3

Herro, D., Quigley, C., Andrews, J., \& Delacruz, G. (2017). Co-Measure: developing an assessment for student collaboration in STEAM activities. International Journal of STEM Education, 4, 26. https://doi.org/10.1186/s40594-017-0094-z 
Hunter, P. (2017). Digital Learning 2.0. Global Focus: The EFMD Business Magazine, 2 (11), 26-29. https://www.globalfocusmagazine.com/digital-learning-2-0/

Jolly, A. (2017). STEM by Design: Strategies and Activities for Grades 4-8. Oxfordshire: Routledge. https://www.routledge.com/STEM-by-Design-Strategies-and-Activitiesfor-Grades-4-8/Jolly/p/book/9781138931060

Kelley, T. R., \& Knowles, J. G. (2016). A conceptual framework for integrated STEM education. International Journal of STEAM Education, 3, 11. https://doi.org/10.1186/s40594-016-0046-z

Kim, D., \& Bolger, M. (2017). Analysis of Korean elementary pre-service teachers' changing attitudes about integrated STEAM pedagogy. International Journal of Science and Mathematics Education, 15, 587-605. https://doi.org/10.1007/s10763-015-9709-3

King, D., \& English, L. D. (2016). Engineering design in the primary school: Applying STEM concepts to build an optical instrument. International Journal of Science Education, 38 (18), 2762-2794. https://doi.org/10.1080/09500693.2016.1262567

Kojayan, A., \& Statti, A. (2021). Extra-Curricular Activities: The Virtual Element. In I. Jaafar \& J. M. Pedersen (Eds.), Emerging Realities and the Future of Technology in the Classroom (pp. 102-119). Hershey, PS: IGI Global. https://doi.org/10.4018/978-17998-6480-6.ch007

Krutii, K., \& Hrytsyshyna, T. (2016). STREAM-education of preschool children: we bring up the culture of engineering thinking. Preschool education, 1, 3-7. http://ukrdeti.com/2.pdf

Land, M. H. (2013). Full STEAM ahead: The benefits of integrating the arts into STEM. Procedia Computer Science, 20, 547-552. https://doi.org/10.1016/j.procs.2013.09.317

Luo, H., Li, G., Feng, Q., Yang, Y., Zuo, M. (2021). Virtual reality in K-12 and higher education: A systematic review of the literature from 2000 to 2019. Journal of Computer Assisted Learning, 37 (1), 887-901. https://doi.org/ 10.1111/jcal.12538

Morze, N. V., Vember, V. P., \& Gladun, M. A. (2019). 3D mapping of digital competency in Ukrainian education system. Information Technologies and Learning Tools, 70 (2), 28-42. https://doi.org/10.33407/itlt.v70i2.2994

Morze, N., Vember, V., Boiko, M., \& Varchenko-Trotsenko, L. (2020). Organization of STEAM lessons in the innovative classroom. Open educational e-environment of modern University, 8, 88-106. https://doi.org/10.28925/2414-0325.2020.8.9 
Murphy, K. M., Cook, A. L., \& Fallon, L. M. (2021). Mixed reality simulations for socialemotional learning. Phi Delta Kappan, $102 \quad$ (6), 30-37. https://doi.org/10.1177/0031721721998152

Musavi, M., Friess, W. A., James, C., \& Isherwood, J. C. (2018). Changing the face of STEM with stormwater research. International Journal of STEM Education, 5, 2. https://doi.org/10.1186/s40594-018-0099-2

Sinatra, G. M., Mukhopadhyay, A., Allbright, T. N., Marsh, J. A., \& Polikoff, M. S. (2017). Speedometry: a vehicle for promoting interest and engagement through integrated STEM instruction. Journal of Educational Research, 110 (3), 308-316. https://doi.org/10.1080/00220671.2016.1273178

Sirakaya, M., \& Sirakaya, D. A. (2020). Augmented reality in STEM education: a systematic review. Interactive Learning Environments. https://doi.org/10.1080/10494820.2020.1722713

Stefanidis, K., Psaltis, A., Apostolakis, K. C., Dimitropoulos, K., \& Daras, P. (2019). Learning prosocial skills through multiadaptive games: a case study. Journal of Computers in Education, 6 (1), 167-190. https://doi.org/10.1007/s40692-019-00134-8

UNESCO. (2020). Education in a post COVID-19 world: Nine ideas for public action. International Commission on the Futures of Education. Retrieved from https://unesdoc.unesco.org/ark:/48223/pf0000373717/PDF/373717eng.pdf.multi

You, H. S., Marshall, J. A., \& Delgado, C. (2018). Assessing students' disciplinary and interdisciplinary understanding of carbon cycling. Journal of Research in Science Teaching, 55 (3), 377-398. https://doi.org/10.1002/tea.21423 